\title{
Impression Management Motivations, Strategies and Disclosure Credibility of Corporate Narratives
}

\author{
Sheehan Rahman \\ Manchester Business School \\ University of Manchester
}

Received: March 31, 2012

Accepted: April 16, 2012 Published: July 1, 2012

doi:10.5296/jmr.v4i3.1576

URL: http://dx.doi.org/10.5296/jmr.v4i3.1576

\begin{abstract}
This paper explores the key factors that influence disclosure credibility of corporate managers. Mercer (2004) provided a critical and comprehensive account of the academic literature on disclosure credibility. This paper finds that investors, while determining the credibility of a management disclosure, examine four basic factors - the situational incentives at the time of the disclosure, management's trustworthiness and competence, the degree of assurance for the message from internal and external sources, and several characteristics of the disclosure such as its precision, venue of release and time horizon.
\end{abstract}

Keywords: Impression management, Disclosure credibility, Narratives 


\section{Introduction}

Discretionary corporate disclosures by the management is often believed to reflect opportunistic behaviour as managers seek to exploit information asymmetries between them and the external users by manipulated reporting (Merkl-Davies \& Brennan, 2007). Such opportunistic behaviour is termed as impression management. Broadly speaking, Hooghiemstra (2000) defined impression management as a branch of social psychology where by an individual displays such behaviour that will yield a favourable assessment by others. Clatworthy \& Jones (2001) and Yuthas et al. (2002) refined this definition from the corporate perspective by stating that impression management involves controlling and manipulating the impression presented to accounting information users, with a view to strategically manipulate their perceptions, and eventually, their decisions (Merkl-Davies \& Brennan, 2007). This can often be done by manoeuvring the information content and its presentation in corporate documents with a view to altering the user's perceptions of the economic performance of the firm (Healy \& Wahlen, 1999; Godfrey et al., 2003). The idea of impression management assumes a weak form of market efficiency where investors do not have enough information to assess managerial bias in the short term. Hence, managers engage in impression management to influence the firm's share price, which can result in misallocation of capital and increase managerial compensation (Adelberg, 1979; Rutherford, 2003; Courtis, 2004; Merkl-Davies \& Brennan, 2007).

\section{Motivations for Impression Management}

Leary \& Kowalski (1990) suggest three major motivations for managers to engage in impression management. First, managers would engage in opportunistic behaviour, seeking to maximize expected returns and minimize expected punishments (Merkl-Davies \& Brennan, 2007). Individuals may engage in impression management if it is relevant for achieving one or several goals, e.g. the maximization of social and material outcomes or the maintenance and enhancement of self-esteem. The value of desired outcomes also affects impression management behaviour - the higher the value attached to particular outcomes, the stronger the motivation for impression management. Also the difference between one's desired and current social image can motivate managers to engage in impression management (Merkl-Davies \& Brennan, 2007). Second, Leary \& Kowalski (1990) state that individuals attempt to make sure that their public image is consistent with their social role. Individuals also construct self-images that match with the values and preferences of larger, more significant groups. In a corporate context, adopting a stakeholder theory, one can state that firms may engage in impression management by following the target value of stakeholder or interest groups (Merkl-Davies \& Brennan, 2007). Third, Leary \& Kowalski (1990) state that impression management depends on manager's current as well as potential future image, which may constrain the impression management strategies adopted. Public failures or embarrassments may induce individuals to engage in impression management for countering or repairing their damaged image (Merkl-Davies \& Brennan, 2007).

\section{Strategies of Impression Management}


There are two types of behaviours that managers may exhibit-concealment or attribution (Merkl-Davies \& Brennan, 2007). Concealment can be achieved either by disguising negative news or by reinforcing positive news, where as attribution is the tendency to claim more responsibility for successes than for failures. Merkl-Davies \& Brennan (2007) identified seven impression management strategies, where one is the attribution of organizational outcomes where as the remaining six are used for concealment. Of these, two attempt to hide bad news either by making the text more difficult to read (reading ease manipulation) or by using persuasive language (rhetorical manipulation). The other four concealment strategies attempt to emphasize good news by focusing on positive words, themes or financial performance (thematic manipulation), by visually biasing the way the information is presented (visual and structural manipulation), by choosing measures that demonstrate the current financial performance favourably (performance comparisons) or by disclosing one number from several to depict financial performance favourably (choice of earnings number).

Reading ease manipulation attempts to use reading difficulty as a proxy for obfuscation, with a view to confuse or distract the readers (Courtis, 2004). Rutherford (2003) noted that managers reduce clarity in writing when they intend to disclose less about the original situation. Merkl-Davies \& Brennan (2007, p. 133) noted that "syntactical complexity makes texts more difficult to read and this is regarded as a proxy for obfuscation". However, there is an extent to which readability can be manipulated because if it is too complex for the reader to understand then the underlying impression would not be managed for the manager's liking. At the same time, managers would intend to perplex the reader to deter them from further investigating the situation. Reading difficulty can either be a result of deliberate manipulation of the managers or simply bad writing (Merkl-Davies \& Brennan, 2007). Although it is difficult to distinguish between the two, lack of skill as a consequence of poor writing is a less likely explanation as disclosure narratives are expected to be written by professionals; firms spend a lot of money to write narrative report sections conveying the intended message as do not want to jeopardise reputation. Prior studies have occasionally found annual report narratives difficult to read, with even sophisticated users experiencing some difficulty in fully understanding financial narratives (Lewis et al., 1986; Courtis, 1986, 2004, Smith \& Taffler, 1992). Jones (1988) found readability to decrease over time, as sales declines and when a firm goes public. The evidence of the relationship between readability and firm performance is mixed; some studies have found that reading difficulty increases as firms exhibit poor performance (e.g. Adelberg, 1979; Subramanian et al., 1993; Courtis, 1998, 2004; Li, 2006) where as others failed to find such relation (e.g. Courtis, 1986, 1995; Baker \& Kare, 1992; Clatworthy \& Jones, 2001; Rutherford, 2003).

Rhetorical manipulation attempts to conceal negative outcomes by using persuasive language (e.g. pronouns and passive voice) by emphasizing on not what firms say but rather how they say it (Pennebaker et al., 2003; Merkl-Davies \& Brennan, 2007). Findings on prior studies are mixed. Thomas (1997) found firms used rhetorical devices while explaining negative firm performance blaming them on circumstances outside the control of managers, suggesting that while narratives suggest and imply, they do not lie. Sydserff \& Weetman (2002) examined the relationship between verbal tone and financial performance and observed limited 
presence of impression management. Yuthas et al. (2002) found that firms with both positive and negative earnings surprises use more rhetorical devices than firms without earnings surprises, suggesting managers do not use narratives to manage impression, but to emphasize honesty and truthfulness.

Thematic manipulation involves concealment by either not reporting bad news, or by reporting it to a lesser extent than favourable news. Managers attempt to present performance information as best as they can, resulting in the prevalence of positive rather than negative words and themes (Schleicher, 2012). Some studies found that managers tend to highlight positive organizational outcomes, regardless of the overall performance (Smith \& Taffler, 2000; Rutherford, 2005; Guillamon-Saorin, 2006). However, such positive bias from the management can only be a reliable indicator of future firm performance if it is ascertained by analysts. Matsumoto et al. (2006) found that such managerial positive bias is not confirmed by analyst opinion and hence is not reflected in future firm performance. Similar assertions have also been made by Scheicher \& Walker (2010) and Schleicher (2012). Lang \& Lundholm (2000) found that optimistic disclosure increases rapidly before new equity public offerings, where as pessimistic disclosure decreases slightly. However after the equity public offering, the mix of tones becomes more neutral, suggesting that, to increase the share price, managers engage in impression management before the offering (Merkl-Davies \& Brennan, 2007).

Visual and structural manipulation attempts to influence the users' perception of firm performance by affecting the manner in which the information is presented. Guillamon-Saorin (2006) asserted that repetition of certain information is used for impression management, and reinforcement occurs when a piece of information is emphasized by using a qualifier. Positive information tends to be more emphasized, and more prominently placed than negative information. Visual emphasis takes place when firms use visual effects such as highlighting, font style and size, bullet point, bold text, colour, etc to make certain information more obvious to the readers (Courtis, 2004; Guillamon-Saorin, 2006). The physical location of information is used to direct the reader's attention towards or away from certain information (Staw et al., 1983; Baird \& Zelin, 2000; Bowen et al., 2005; Elliot, 2006; Guillamon-Saorin, 2006; Kelton, 2006).

Firms choose to emphasise such performance comparisons that place them in the best possible light. Merkl-Davies \& Brennan (2007) found that firms may either choose the lowest prior-period benchmark earnings number in order to report the highest year-on-year earnings (benchmark earnings number), or may compare performance indicators with reference points, such as its own past performance or industry averages and competitors (performance referents). Lewellen et al. (1996) found that to enable managers to overstate share-return performance, the benchmark for share price performance is biased downwards. Schrand \& Walther (2000) found that in order to report the highest year on year increase in earnings, managers tend to select the lowest prior period comparative benchmarks. Cassar (2001) observed that firms with improving performance usually disclose share performance graphs voluntarily. 
Firms may specifically choose certain earnings number while omitting others in order to view their performance favourably. Guillamon-Saorin (2006) found that firms select the highest earnings number to depict their performance positively. A wealth of research has been conducted on pro-forma earnings (Merkl-Davies \& Brennan, 2007). As they are earning numbers other than those calculated under GAAP, pro-forma earnings can be computed in many different ways. Bowen et al. (2005) explains that pro-forma earnings may be used by managers to make the firm look more profitable, introducing positive bias in corporate narratives.

Performance attribution theory suggests that managers maximize self-interest by attributing positive outcomes to internal factors and excusing negative outcomes to external factors (Clatworthy \& Jones, 2003). The context and motive play a vital role in self-serving tendencies (Aerts, 2005). Negative news are explained using accounting theory where as positive news are explained using clear cause and effect statements (Aerts, 1994). However, the effectiveness of performance attribution depends on the extent to which the explanations are credible (Barton \& Mercer, 2005).

\section{Impression Management and Credibility of Corporate Narratives}

Given that managers may use various strategies for impression management, the underlying question is that if managing the information affects the credibility of the message. If users can forecast that managers are undertaking impression management strategies, then the credibility of the message is likely to be very low.

Disclosure credibility is the user's perceptions of the believability of a particular disclosure (Mercer, 2004). If a message contained in the annual report or interim management statement is believable from the investor's perspective, that message has credibility, and investors as well as other users of the disclosure information will base their actions on the message of the disclosure. Conversely, if such a statement is not deemed to be trustworthy, then users should ignore it while making decisions. It must be noted that disclosure credibility may not be the same as management credibility, although previous accounting literature has sometimes interchangeably used the two notions. Mercer (2004) purported that disclosure credibility is analyzed or evaluated by investors, separately for each narrative or disclosure. Hence the same firm may obtain different appraisals from investors or users for different disclosures. Conversely, management credibility is often a function of the credibility of the firm's managers, i.e. their competence and trustworthiness (Hovland et al., 1953; Birnbaum \& Stegner, 1979; Petty \& Wegener, 1998; Mercer, 2004). Hence the entire firm's trustworthiness determines the management credibility.

The concerns about disclosures seem to be ever present since the time financial scandals such as Enron and WorldCom have demolished investor confidence on the reliability of financial disclosures (Barrett, 2002). Generally, disclosures by the management can only be a useful source of information for investors and other users if they are deemed to be reliable and credible (Mercer, 2004). If management disclosures are not believed by investors to be credible, then they would not make, for instance, buy, hold or sell decisions on the basis of such information, and hence such disclosures will generally be irrelevant for investor 
decision making, and would not have an influence on share price or investor behaviour. Investors are not only seen to react to surprise information contained in the disclosure but also react to the extent or degree of the disclosure, and hence both may be seen as equally important for determining the credibility of a disclosure (Jennings, 1987). Due to such importance of the integrity of management disclosures, recent research has identified a number of factors that may influence disclosure credibility.

\section{Factors Influencing the Credibility of Management Disclosures}

Mercer (2004) identified four broad factors of disclosure credibility—situational incentives at the time of the disclosure, management's competence and trustworthiness, i.e. credibility, the degree of assurance provided, both externally and internally, and the characteristics of the disclosure itself.

The credibility of a disclosure is influenced by the perceived incentive of the source of the disclosure. Studies suggest that the audience are less likely to believe messages that are reflective of the source's incentives. People view messages reflective of the source's incentives to those incentives, rather than with the source's true beliefs (Kelley, 1972, Mercer, 2004). Similarly, messages inconsistent with the source's incentives are inferred to reflect the source's ulterior incentives. For instance, Eagly et al. (1978) performed a study with two groups of participants on the credibility of a politician's speech. For the same speech, the first subsample was informed that it was consistent with the audience's beliefs where as the second subsample was informed that they were not. The participants rated the politician's speech as less credible when they were consistent with audience beliefs, implying that the respondents found speeches consistent with the audience's beliefs to be less credible, as they were consistent with the politician's incentive to "play with the crowd" (Mercer, 2004, p. 187)

Agency theory suggests that the incentives of mangers are likely to be different from that of owners. Where owners are concerned about the share price and profitability of the enterprise, managers are concerned about their salaries and other forms of compensation, promotion and termination prospects, etc. Hence investors are unlikely to believe management disclosures when the management has high motives for being untruthful. Prior studies suggest that managers tend to have greater incentives to disclose positive information than negative information. Hence bad news are expected to be, and are often viewed, to be more credible than good news, ceteris paribus (McNichols, 1989; Williams, 1996; Hutton et al., 2003). In addition, management disclosures that contain bad news result in greater stock price reactions and more analyst forecast revisions than those containing good news (Hassell et al., 1988; Williams, 1996; Cairney \& Richardson, 1999; Hutton et al., 2003). Comparing the disclosure credibility of financially distressed and non-financially distressed firms, Koch (1999) stated that firms in the verge of financial disclosures or bankruptcy have greater motivations to provide misleading statements as they have greater benefits and fewer costs of providing inaccurate narratives. Frost (1997) supplements this by stating that disclosures by financially distressed firms yield lesser share price reaction that firms in good financial position. 
The credibility of the managers of the firm often influences the believability of a disclosure (Birnbaum \& Stegner, 1979). Managers who can develop reputations for credible disclosures are able to increase the believability of their disclosures subsequently. Hence the management's prior forecast accuracy affects the size of the analyst's forecast revisions for subsequent forecasts (Williams, 1996, Hirst et al., 1999, Hodge et al., 2000).

The degree of assurance provided for a management disclosure affect its credibility. This assurance can be provided both from an internal or an external source. External sources of such assurance are provided by parties such as financial analysts, auditors, journalists. Internal sources of such assurance are provided by board of directors, audit committee, and internal auditors (Mercer, 2004).

Various studies examine the effects of auditing on the credibility of disclosure to find that audited messages are more credible than non-audited messages, to users such as bankers and financial analysts (Libby, 1979; Leftwich, 1983; Blackwell et al., 1998; Hodge, 2001). The evidence of this is demonstrated by Blackwell et al. (1998) who found that bankers charge lower interest rates to firms providing audited financial statements and by Leftwich (1983) who stated that banks required private companies to supply audited financial statements (Mercer, 2004). The opinions of business journalists may affect investor's perceptions of disclosure credibility. For instance, Barrett (2002) informed (Mercer, 2004, p. 189-190):

The day after an article in 'The New York Times' criticized IBM's method of reporting sale gain in one of its businesses, IBM's share price dropped by $5 \%$.

The reactions of financial analysts to disclosures of management can also affect their credibility. For instance Gogoi (2001) stated (Mercer, 2004, p.190):

When analyst David Tice published a newsletter in October 1999 accusing Tyco of providing misleading disclosures about its acquisitions, investors questioned the credibility of Tyco's disclosures and the stock price fell precipitously.

Similarly Li (2002) stated (Mercer, 2004, p.190):

When JP Morgan analyst Thomas Lee ... criticized Nextel's bad debt and customer turnover disclosures, Nextel's stock fell $5 \%$ on the day the report was released.

Assurance may also be derived from sources internal to the firm. An independent internal audit committee signifies diligence and tends to assure higher quality disclosures. Mercer (2004) noted that several studies found that firms with independent board of governors and internal audit committees (i.e. those that carry a significant number of external members not otherwise related to the firm), or where the board and audit committee meets more frequently and have greater expertise in financial affairs experience less 'fraud' and earnings management and may experience higher market valuations (Beasley, 1996; Klein, 1999; Black et al., 2003). Internal auditors are expected to screen out errors resulting from a firm's weak or inefficient internal control system, and hence if investors can evaluate the quality of internal audit, firms with rated with a strong internal audit committee signifies credible disclosure (Mercer, 2004). 
The disclosure's characteristics in terms of its precision, venue and time horizon often influence its assessment and credibility. Not all management forecasts are similarly precise (Mercer, 2004). Imprecise disclosure suggests uncertainty of the management and is deemed to be less credible than precise ones (Hassell et al., 1988; King et al., 1990). Investors are more confident depending on one point of forecast than a range of forecasts (Hirst et al., 1999) and more precise results have stronger relationships between unexpected earnings and unexpected returns (Baginski et al., 1993).

Managers may disclose information in various places, such as in audited financial statements, meetings with reporters, conference calls and analysts, annual shareholder's meetings, or special press releases (Mercer, 2004). Difficult-to-understand messages are most persuasive when they are written, and easy-to-understand messages are most persuasive when they are communicated through videotapes (Chaiken \& Eagley, 1976). The time horizon of disclosure also affects its credibility. For instance, forecasts about the short term (e.g. interim statements) are perceived to be more credible than those about the long term as managers are presumed to have better information about more immediate outcomes (Mercer, 2004). In the same go, Pownall et al. (1993) demonstrated that interim management earnings forecasts generate greater stock price reactions than annual management earnings forecasts.

\section{Concluding Remarks}

Do impression management strategies work for the managers? Recent evidence remains divided. Managers have been ever persistent by using increased levels of selectivity and vagueness in their financial reporting rather than outright misrepresentations (Schleicher \& Walker, 2010; Schleicher, 2012). Phillips \& Eder (2011) observe that in the aftermath of the euro debt crisis investors in the US have shown increasing preference for investing in junk bonds. This suggests that carefully constructed impression management strategies may serve managerial motives. However, despite managers' attempts to portray their firm's position in favourable light, impression management strategies may not always work. Reasons include the repercussions of the global credit crisis and euro debt crisis. Investors have chosen to sell stocks of firms in emerging markets in Europe like Poland, fearful that earnings would decline by the global downturn (Phillips \& Eder, 2011). In the same go, Candelon \& Palm (2010) caution that the recent developments in Greece can lead to a contagious debt crisis in other capital markets across Europe.

This paper has explored Mercer's (2004) determinants of disclosure credibility. When the management has greater incentives to mislead, or are not very reputable and trustworthy, or when there is a lack of adequate assurance from internal or external sources, disclosures are deemed to be less credible. In addition, certain traits of the disclosure itself, including its precision, venue and time horizon can affect its credibility for investor assessment (Mercer, 2004). What have remained unexplored in this paper are the interactions among and between various disclosure characteristics, understanding of which can provide firms with greater control to adjust these characteristics in the future.

\section{References}

Adelberg, A.H. (1979). Narrative disclosures contained in annual reports: means of communication or manipulation. Accounting and Business Research, 10, 179-189. 
Aerts, W. (1994). On the use of accounting logic as an explanatory category in narrative accounting disclosures. Accounting, Organizations and Society, 19(4/5), 337-353. http://dx.doi.org/10.1016/0361-3682(94)90001-9

Aerts, W. (2005). Picking up the pieces: impression management in the retrospective attributional framing of accounting outcomes. Accounting, Organizations and Society, 30, 493-517. http://dx.doi.org/10.1016/j.aos.2004.07.001

Baginski, S., Conrad, E. \& Hassell, J. (1993). The effects of management forecast precision on equity pricing and on the assessment of earnings uncertainty. The Accounting Review, 68(4), 913-927.

Baird, J.E. \& Zelin, R.C. (2000). The effects of information ordering on investor perceptions: an experiment utilizing president's letters. Journal of Financial and strategic Decisions, 13(3), 71-81.

Baker, H.E. \& Kare, D.D. (1992). Relationship between annual report readability and corporate financial performance. Management Research News, 15(1), 1-4. http://dx.doi.org/10.1108/eb028188

Barrett, A. (2002, March 4). Slammed! Investors are telling companies that creative accounting will no longer fly. Business Week, p. 34.

Barton, J. \& Mercer, M. (2005). To blame or not to blame: analysts' reactions to explanations of poor management performance. Journal of Accounting and Economics, 39, 509-533. http://dx.doi.org/10.1016/j.jacceco.2005.04.006

Beasley, M. (1996). An empirical analysis between the relationship between the board of director composition and financial statement fraud. The Accounting Review, 71(4), 443-465.

Birnbaum, M. \& Stegner, S. (1979). Source credibility in social judgement: bias, expertise and judges' point of view. Journal of Personality and Social Psychology, 37, 48-78. http://dx.doi.org/10.1037/0022-3514.37.1.48

Black, B., Jung, H. \& Kim, W. (2003). Does corporate governance affect firm's market values? Evidence from Korea. Working Paper, Stanford Law School.

Blackwell, D., Noland, T. \& Winters, D. (1998). The value of auditor assurance: evidence from loan pricing. Journal of Accounting Research, 36(1), 57-70. http://dx.doi.org/10.2307/2491320

Bowen, R.M., Davis, A.K. \& Matsumoto, D.A. (2005). Emphasis on pro-forma versus GAAP earnings in quarterly press releases: determinants, SEC intervention and market reactions. The Accounting Review, 80(4), 1011-1038. http://dx.doi.org/10.2308/accr.2005.80.4.1011

Cairney, T. \& Richardson, F. (1999). The credibility of management forecasts of annual earnings. Working Paper, Florida Atlantic University.

Candelon, B. \& Palm, F. (2010). Banking and debt crisis in Europe: the dangerous Liaisons? De Economist, 158(1), 81-99. http://dx.doi.org/10.1007/s10645-010-9138-1 
Casser, G. (2001). Self-serving behaviour and the voluntary disclosure of capital market performance. Accounting Research Journal, 14(2), 126-137.

Chaiken, S. \& Eagley, A. (1976). Communication modality as a determinant of message persuasiveness and message comprehensibility. Journal of Personality and Social Psychology, 34(4), 605-614. http://dx.doi.org/10.1037/0022-3514.34.4.605

Clatworthy, M. \& Jones, M.J. (2001). The effect of thematic structure on the variability of annual report readability. Accounting, Auditing and Accountability Journal, 14(3), 311-326. http://dx.doi.org/10.1108/09513570110399890

Clatworthy, M. \& Jones, M.J. (2003). Financial reporting of good news and bad news: evidence from accounting narratives. Accounting and Business Research, 33(3), 171-185. http://dx.doi.org/10.1080/00014788.2003.9729645

Courtis, J. K. (1986). An investigation into annual report readability and corporate risk-return relationships. Accounting and Business Research, 16, 285-294.

Courtis, J. K. (1995). Readability of annual reports: Western versus Asian evidence. Accounting, Auditing and Accountability, 8-17. http://dx.doi.org/10.1108/09513579510086795

Courtis, J. K. (1998). Annual report readability variability: tests of the obfuscation hypothesis. Accounting, Auditing and Accountability Journal, 11(4), 459-471. http://dx.doi.org/10.1108/09513579810231457

Courtis, J.K. (2004). Corporate report obfuscation: artefact or phenomenon? British Accounting Review, 36(3), 291-312. http://dx.doi.org/10.1016/j.bar.2004.03.005

Eagly, A., Wood, W., \& Chaikem, S. (1978). Causal inferences about communicators and their effect on opinion change. Journal of Personality and Social Psychology, 36, 424-435. http://dx.doi.org/10.1037/0022-3514.36.4.424

Elliot, W.B. (2006). Are investors influenced by pro-forma emphasis and reconciliations in earnings announcements? The accounting Review, 81(1), 113-133. http://dx.doi.org/10.2308/accr.2006.81.1.113

Frost, C. (1997). Disclosure policy choices of UK firms receiving modified audit reports. Journal of Accounting and Economics, 23(2), 163-187. http://dx.doi.org/10.1016/S0165-4101(97)00006-2

Godfrey, J., Mather, P. \& Ramsay, A. (2003). Earnings and impression management in financial reports: the case of CEO changes. Abacus, 39(1), 95-123. http://dx.doi.org/10.1111/1467-6281.00122

Gogoi, P. (2001, September 3). Making bad news pay. Business Week, p. EB24.

Guillamon-Saorin, E. (2006). Impression management in financial reporting: evidence from the UK and Spain. Unpublished doctoral dissertation, University College Dublin. 
Hassell, J., Jennings, R. \& Lasser, D. (1988). Management earnings forecasts; their usefulness as a source of firm-specific information to security analysts. Journal of Financial Research, 11(4), 303-319.

Healy, P.M. \& Wahlen, J.M. (1999). A review of earnings management literature and its implications for standard setting. Accounting Horizons, 13, 365-383. http://dx.doi.org/10.2308/acch.1999.13.4.365

Hirst, D.E., Koonce, L. \& Miller, J. (1999). The joint affect of management's prior forecast accuracy and the form of its financial forecast on investor judgements. Journal of Accounting Research, Supplement, 1-24.

Hodge, F., Hopkins, P. \& Pratt, J. (2000). Classification discretion, reporting reputation, and disclosure credibility: the case of hybrid securities. Working Paper, Indianan University.

Hodge, F., Hopkins, P. \& Pratt, J. (2001). Hyper-linking unaudited information to audited financial statements; effects on investor judgements. The Accounting Review, 76(4), 675-691. http://dx.doi.org/10.2308/accr.2001.76.4.675

Hoogheimsrtra, R. (2000). Corporate communication and impression management-new perspectives: why companies engage in social reporting. Journal of Business Ethics, 27, 55-68. http://dx.doi.org/10.1023/A:1006400707757

Hovland, C., Janis, I. \& Kelly, H. (1953). Communication and Persuasion. New Haven, CT: Yale University Press.

Hutton, A., Miller, G. \& Skinner, D. (2003). The role of supplementary statements with management earnings forecast. Journal of Accounting Research, 25(1), 90-110.

Jennings, R. (1987). Unsystematic security price movements, management earnings forecasts, and revisions in consensus analyst earnings forecasts. Journal of Accounting Research, 25(10), 90-110. http://dx.doi.org/10.2307/2491260

Jones, M.J. (1988). A longitudinal study of the readability of the chairman's narratives in the corporate reports of a UK company. Accounting and Business Research, 18(2), 297-306. http://dx.doi.org/10.1080/00014788.1988.9729377

Kelley, H. (1972). Attribution in social interaction. Attrbutions: Perceiving the Causes of Behavior, ed. Jones, E., Kanouse, D., Kelley, H., Nisbett, R., Valins, S., Weiner, B. Published Morrison NJ: General Learning Press,151-174.

Kelton, A.S. (2006). Internet financial reporting: the effects of hyperlinks and irrelevant information on investor judgements. Unpublished doctoral dissertation, The University of Tennessee, Knoxville.

King, R., Pownall, G. \& Waymire, G. (1990). Expectations adjustment via timely management forecasts: review, synthesis and suggestions for future research. Journal of Accounting Literature, 9, 113-144. 
Klien, A. (1999). Audit committee, board of director characteristics, and earnings management. Journal of Accounting and Economics, 33, 375-400. http://dx.doi.org/10.1016/S0165-4101(02)00059-9

Koch, A. (1999). Financial distress and the credibility of management forecasts. Working Paper, Caregie Mellon University.

Lang, M. \& Lundholm, R. (2000). Voluntary disclosure and equity offerings: reducing information asymmetry or hyping the stock? Contemporary Accounting Research, 17(4), 623-662. http://dx.doi.org/10.1506/9N45-F0JX-AXVW-LBWJ

Leary, M.R. \& Kowlaski, R.M. (1990). Impression management: a literature review and two-component model. Psychological Bulletin, 107(1), 34-47. http://dx.doi.org/10.1037/0033-2909.107.1.34

Leftwich, R. (1983). Accounting information in private markets: evidence from private lending agreements. The Accounting Review, 64(1), 1-27.

Lewellen, W.G., Park, T. \& Ro., B.T. (1996). Self-serving behaviour in managers discretionary information disclosure decisions. Journal of accounting and Economics, 21(2), 227-251. http://dx.doi.org/10.1016/0165-4101(95)00417-3

Lewis, N.R., Parker, L.D., Pound, G.D. \& Sutcliffe, P. (1986). Accounting report readability: the use of readability techniques. Accounting and Business Research, 16(Summer), 199-213. http://dx.doi.org/10.1080/00014788.1986.9729318

Li, F. (2006). Annual report readability, current earnings and earnings persistence. Working Paper, University of Michigan.

Li., K. (2002, October 8). Nextel defends its accounting. The Street.com, p.1.

Libby, R. (1979). Bankers' and auditors' perception of the message communicated by the audit report. Journal of Accounting Research, 17 (1), 99-122. http://dx.doi.org/10.2307/2490308

Matsumoto, D., Pronk, M \& Roelofsen, E. (2006). Do analysts mitigate optimism by management? Working Paper, University of Washington.

McNicols, M. (1989). Evidence of information asymmetries from management earnings forecasts and stock returns. The Accounting Review, 58(1), 23-42.

Mercer, M. (2004). How do investors assess the credibility of management disclosures? Accounting Horizons, 18(3), 185-196. http://dx.doi.org/10.2308/acch.2004.18.3.185

Merkl-Davies, D.M. \& Brennan, N.M. (2007). Discretionary disclosure strategies in corporate narratives: incremental information or impression management? Journal of Accounting Literature, 26, 116-194. 
Pennebaker, J.W., Mehl, M.R. \& Neiderhoffer, K. (2003). Psychological aspects of natural language use: our words, our selves. Annual Review of Psychology, 54, 547-577. http://dx.doi.org/10.1146/annurev.psych.54.101601.145041

Petty, R. \& Wegener, D. (1998). Attitude change: multiple roles for persuasion variables. The Handbook of Social Psychology (Vol. I), ed. Gilbert, D., Fiske, S. and Lindzey, G. Published Boston, MA: McGraw-Hill, 323-390.

Phillips, M. \& Eder, S. (2011, January 11). A month to remember for the markets. Wall Street Journal (Eastern), 258 (104), pp.C1-C2.

Pownall, G., Wasley, C. \& Waymire, G. (1993). The stock price effects of alternative types of management earnings forecasts. The Accounting Review, 68 (4), 896-912.

Rutherford, B.A. (2003). Obfuscation, textual complexity and the role of regulated narrative disclosure in corporate governance. Journal of Management and Governance, 7, 187-210. http://dx.doi.org/10.1023/A:1023647615279

Rutherford, B.A. (2005). Genre analysis of corporate annual report narratives: a corpus linguistics based approach. Journal of Business Communication, 42(4), 324-348. http://dx.doi.org/10.1177/0021943605279244

Schrand, C., \& Walther, B.R. (2000). Strategic benchmarks in earnings announcements: the selective disclosure of prior period earnings components. The Accounting Review, 75(2), 151-177. http://dx.doi.org/10.2308/accr.2000.75.2.151

Schleicher, T. (2012). When is good news really good news? Working paper, University of Manchester.

Schleicher, T., \& Walker, M. (2010). Bias in the tone of forward looking narratives. Accounting and Business Research, 40, 371-390. http://dx.doi.org/10.1080/00014788.2010.9995318

Smith, M., \& Taffler, R.J. (1992). Readability and understandability: different measures of the textual complexity of accounting narrative. Accounting, auditing and Accountability Journal, 13(5), 624-646. http://dx.doi.org/10.1108/09513570010353738

Smith, M., \& Taffler, R.J. (2000). The chairman's statement: a content analysis of discretionary narrative disclosures. Accounting, Auditing and Accountability Journal, 13(5), 624-646. http://dx.doi.org/10.1108/09513570010353738

Staw, B.M., McKechnie, P.I., \& Puffer, S.M. (1983). The justification of organizational performance. Administrative Science Quarterly, 28, 582-600. http://dx.doi.org/10.2307/2393010

Subramanian, R., Insley, R., \& Blackwell, R.D. (1993). Performance and readability: a comparison of annual reports and profitable and unprofitable corporations. The Journal of Business Communication, 30(1), 49-60. http://dx.doi.org/10.1177/002194369303000103 


\section{Macrothink}

Journal of Management Research ISSN 1941-899X 2012, Vol. 4, No. 3

Sydserff, R., \& Weetman, P. (2002). Developments in content analysis: a transitivity index and DICTION scores. Accounting, Auditing and Accountability Journal, 12(4), 1459-1488.

Thomas, J. (1997). Disclosure in the marketplace: the making of meaning in annual reports. The Journal of Business Communication, 34(1), 47-66. http://dx.doi.org/10.1177/002194369703400103

Williams, P. (1996). The relation between a prior earnings forecast by management and analyst response to a current management forecast. The Accounting Review, 71(1), 103-113.

Yuthas, K., Rogers, R., \& Dillard, J.F. (2002). Communicative action and corporate annual $\begin{array}{llll}\text { reports. Journal of Business } & \text { Ethics, 41(1-2), } 157 .\end{array}$ http://dx.doi.org/10.1023/A:1021314626311 